\title{
Assessment of lobster resources management with ecosystem approach in Pangandaran Water
}

\author{
Andrias S. Samusamu ${ }^{1, *}$ and Lukijanto $^{2}$ \\ ${ }^{1}$ School of Environmental Science, Universitas Indonesia \\ ${ }^{2}$ Ministry of Coordinating Marine Affairs Republic Indonesia
}

\begin{abstract}
The development of lobster production in pangandaran during the last decade (2006-2013) is in the range of 0.5 to 12 ton/year with an increasing trend in 2010-2013, but then increasingly decline since 2014. Pressure on lobster populations followed by a decrease in environmental carrying capacity may threaten the lobster's sustainability capacity to grow and develop naturally. This paper aims to analyze the reference values of the components required in the application of EAFM (Ecosystem Approach to Fisheries Management) to manage lobsters in Pangandaran. The six domains in EAFM include: a) resource domain, b) fishing techniques, c) habitat and ecosystem, d) economy, e) social, and f) institutional domain in general it will affect the sustainable management of lobsters in the Pangandaran. The method used in this research is AHP (Analytic Hierarchy Process). Research results show that the coral cover is an important aspect that cannot be separated from the management of lobster resources. Thus, the right management option is that both central and local governments need to reassure the effectiveness of the regulatory tools for the management of lobsters and conduct continuous and comprehensive lobster stock assessments while considering socioeconomic aspects in the context of sustainable lobster management in the Pangandaran.
\end{abstract}

\section{Introduction}

One of the lobster producers in Indonesia is Pangandaran Regency, West Java. Catching lobsters in Pangandaran has been going on since the 1990s. The development of lobster production during the last decade (2006-2013) is in the range of 0.5 to 12 tons / year with a trend that increased in 2010-2013, but then declined since 2014. The increase in lobster production in the initial period is expected to increase demand, especially export market, while the tendency tends to decrease, perhaps a pattern that tends to be extractive and less environmentally friendly [15].

Pressure on the lobster population followed by a decrease in the sustainability capacity of lobsters can grow and develop naturally. According to [14], the use of fish resources is

\footnotetext{
* Corresponding author: buce.prpt@gmail.com
} 
dominated by fishing activities in nature. Extraction of extractive lobsters in nature can negatively affect coral reefs as lobster habitat and lobster's own living habits $[1,23,25,15$, 20]. On the other hand, the application of the Ministerial Regulation Permen-KP/Number 1 /Year 2015 and Permen-KP/Number 56/Year 2016 is expected to encourage a significant decrease in production. Such conditions will affect the socio-economic conditions of the people in the Pangandaran region, so that the tip of the lobster's resources cannot be relied upon as a source of income for fishermen and foreign exchange.

This paper aims to manage the Fisheries Management Ecosystem Approach to manage lobsters in the Pangandaran Regency area. The domains studied in EAFM include: a) domain of resources, b) fishing techniques, c) habitat and ecosystems, d) economy, e) social, and f) institutional domains. The six domains at EAFM will certainly be interdependent and affect each other so that in general they will influence the management of lobsters in the Pangandaran region so that they can support Life Cycle Assessment as a Metric to Achieve Sustainable Development Goals.

\section{Methods}

The primary data collection method was conducted through interviews of twenty-one respondents using structured questionnaire compiled based on Analytic Hierarchy Process [22]. These respondents consisted of fishermen represented by 4 heads of fishermen groups (Rukun Nelayan), local governments represented by 2 persons from Department of Food Security of Forestry and Fisheries and 2 peoples from Water Police, and 4 researcher, 2 people each from the Fishery Research Center, Ministry of Marine Affairs and Fisheries and 2 people from the Oceanographic Research Center, Indonesian Institute of Sciences (LIPI). Secondary data were obtained from literature studies related to lobster research in Southern Java, particularly in Pangandaran area and reviewing other relevant reference.

The preparation of questionnaires consists of three parts in the form of hierarchy namely focus/goals, criteria and alternatives. The criteria intended here are the criteria of each EAFM domain (Resources, fishing techniques, habitats and ecosystems, social, economic and institutional). Meanwhile, alternatives are the principles put forward by [10] among others: Option I (Minimized the effect of fisheries to the ecosystem), Option II (Precautionary approach should take based on an incomplete information should) and Option III (Balancing the human and ecosystem welfare and property rights). Questionnaires are prepared by pairwise comparison between criteria and alternatives. The calculation of importance level of each variables is done based on important values ranging from 1-9 (Table 1).

Table 1. Values of interest scale and its explanation for AHP.

\begin{tabular}{|c|l|l|}
\hline Intensity of & \multicolumn{1}{|c|}{ Definition } & \multicolumn{1}{c|}{ Explanation } \\
\hline 1 & Equal importance. & Activities contribute equally to the objective. \\
\hline 3 & $\begin{array}{l}\text { Weak importance of one over } \\
\text { another. }\end{array}$ & $\begin{array}{l}\text { Experience and judgment slighly favor one } \\
\text { activity over another. }\end{array}$ \\
\hline 5 & $\begin{array}{l}\text { Essential or Strong } \\
\text { importance. }\end{array}$ & $\begin{array}{l}\text { Experience and judgment strongly favor one } \\
\text { activity over another. }\end{array}$ \\
\hline 7 & Demonstrated importance. & $\begin{array}{l}\text { Activity is strongly favored and it's } \\
\text { dominance is demonstrated in practice. }\end{array}$ \\
\hline 9 & Absolutely importance. & $\begin{array}{l}\text { The evidence favoring one activity over } \\
\text { another is of the highest possible order of } \\
\text { affirmation. }\end{array}$ \\
\hline $2,4,6,8$ & $\begin{array}{l}\text { Intermediate values between } \\
\text { the two adjacent judgments. }\end{array}$ & When compromise is need. \\
\hline
\end{tabular}


Data analysis in this study used AHP (Analytic Hierarchy Process) method to assess the component of EAFM (Ecosystem Approach to Fisheries Management). The multidimensional and complex problem can be solved by the AHP method [16, 13, 21]. The steps in AHP analysis modification follows [15]:

\section{Results and discussion}

\subsection{Priority criteria based on EAFM domain}

\subsubsection{Resource domain}

Lobster's TAC criteria show the highest weight value of the three criteria in the resource domain that is equal to 0.09639 then followed (C3) by lobster size criteria (0.09566) and (C2) composition of lobster's species (0.03811). Based on interview with fishermen, in the last two years there has been a decrease in the number of fishing trips of fishing gear that operated to catch lobster and directly resluted in a decrease in the number of lobster catch. This condition can give positive effect for the increase of lobster population in nature.

This condition also reinforced by the enactment of Regulation of the Minister of Maritime Affairs and Fisheries RI Number 1/PERMEN-K /2015 and Number 56/PERMEN-KP/2016. However, this should be supported by review and re-adjustment of the Permen related to the ban on lobster catches by carapace length $>8$ and/or with weight $>200 \mathrm{gr}$, because based on information from fishermen, most of the catch dominated by lobster sized $<8 \mathrm{~cm}$ and / or has weight $<200 \mathrm{gr}$, which is then released back by the community (if found life) or taken for private consumption (when caught dead). In addition, there are several lobster types that in fact have ripe gonads on carapace sized $<8 \mathrm{~cm}$ and / or with a weight $<200$ gr. Review and re-adjustment of Permen is necessary so that people allowed to catch lobster for cultivation needs.

\subsubsection{Fishing technique domain}

Modification of fishing gear and fishing aids (C4) (0.05349) and (C5) fishing selectivity (0.05623). Catching lobsters that can be done positively for the sustainability of the resources within them. Modification of gill net fishing gear which is the main lobster fishing tool in Pangandaran is done by coating (combing) part or all of the mesh body with different mesh size (Mesh size 4 inch and 6 inch). Operated gill net ranges from 1 to 10 sets with the length of one set are from 20 to $40 \mathrm{~m}$.

Based on the result of interview with fishermen, the net used in each fishing operation has depreciated by about $1-5 \%$. This depreciation is the net damage caused by impact of the waves hit and caught in the coral reefs. Nets that have been caught in the coral reef in practice will be cut immediately and mostly left in a position still wrapped around the body of coral reefs. The rest of the caught nets will become ghost fishing that can directly cause damage to the coral reefs and can decrease the production of fisheries [9].

\subsubsection{Habitat and ecosystem domain}

Weighting result on each criterion ( 3 criteria) in the habitat and ecosystem domain, criteria for coral cover (C6) are 0.13239; turbidity level (NTU) to determine the rate of water sedimentation (C7) (0.04276); and the impact of climate change on water \& habitat (C8) (0.03668). Based on data from [15], it is known that coral cover in Pangandaran is already 
in low status that is $<25 \%$. Damage to coral reefs can be restored through coral reef habitat improvements. This improvement can be done by: prevention and/or cessation of activities that could damage coral reef habitat, use/implementation of building construction that conforms to ecological principles, use/technical application of habitat improvement, and/or creation of artificial habitats.

Creation of artificial habitat can be done by making artificial reefs that use biorock media [12], concrete and environmentally friendly media (Permen KP/Number 24/Year 2016 on Procedures for rehabilitation of coastal areas and small islands). According to [15], designation of artificial reefs as "lobster house" is still very few in number, in principle, ecologically, it has same function with artificial reefs in general but the design, construction, and configuration of artificial reefs as lobster house should be tailored to lobster habitat preferences that have certain characteristics that are different from the artificial reef for fish.

\subsubsection{Social domain}

The criteria for stakeholder participation (C9) have the highest weight of 0.06277 while the fisheries conflict criteria (C10) only has a score of 0.04741 . This shows that participation from various stakeholders still needs to be improved. Active participation from the Local Government regarding the existence and management of lobster resources in the Pangandaran region is still very low. This can be seen from the lack of socialization about Permen KP/Number 1/Year 2015 and Permen KP/Number 56/Year 2016 which in practice this Permen is then associated with the UU. RI Number 31 year 2004 so that those who violate the Permen shall be subject to a maximum sentence of 6 (six) years imprisonment and fines as much as Rp1.500.000.000- (One billion five hundred million rupiah).

In the other hand, the active participation of fishermen representing the community component in the Pangandaran area is still experiencing the constraints caused by the low human resources in the fishing community, which indirectly resulting in low understanding of the sustainable management of lobster resources. The characteristics of the family in Pangandaran with education participation which are still incorporated in the categories of building poor families there are difficult to develop themselves [18].

\subsubsection{Economy domain}

A criterion for asset ownership (C11) that is (0.05511) is a criterion that has the lowest weighting value of both criteria in the economic domain. Meanwhile, criterion of fishery household income $(\mathrm{C} 12)$ is criterion with highest weight value that is $(0.8160)$. Today, people who are particularly lobster catchers desperately need alternative livelihoods, including cultivation lobster. [8] suggested that the magnitude of the potential of lobster seeds opens up opportunities for the development of lobster enlargement cultivation activities, so that people get alternative livelihoods in lieu of activities to catch lobster. This is because in terms of income, fishermen who catch lobsters are fishermen who have a very low amount of income when compared to other fishermen in the Pangandaran region.

The ownership status of business assets related to lobster fisheries in Pangandaran region also affects total income of lobster fishermen. Most of the assets are not owned by fishermen but are owned by individuals and/or business entities or companies engaged in fisheries (KUD). According to [19], the nature of the ownership of the means of fishing is ultimately connected with the profit received from the fishery business. The nature of ownership of this means of fishing in addition to show the acceptance of profit also indicates the level of independence of the surrounding population on the ownership of 
fishery business assets that are not dependent on outsiders. The low level of asset ownership is one of the factors causing poverty [17].

\subsubsection{Institutional domain}

The criteria that get the highest weight are the violation frequency criterion $(\mathrm{C} 13)$ that is equal to 0.07321 . Subsequently followed by $\mathrm{C} 14$ criteria, management regulations (0.07178) and criteria C15, stakeholder capacity (0.05641). Components of violations with high frequency are those related to lobster catching practices that are still below the size set by Permen KP/Number 1/Year 2015 and Permen KP/Number 56/Year 2016. Based on interview result, it is known that from the total catch, lobsters with carapace size $<8 \mathrm{~cm}$ and/or weight of 200 gr can reach $40-60 \%$. According to [3] the establishment of special regulations specifically as the implementing rule on the issuance of the various regulations that exist in regulating the protection of fishery resources is very important to establish. Therefore, catching lobsters below the established size can be controlled through the establishment of a Local Regulation on lobster fishing based on the size distribution of each type of lobster in the Pangandaran area.

The weighting result of each criterion in each research domain with a consistency ratio of $9.6 \%$ shows that, the criteria of coral cover (C6) on the habitat and ecosystem domain is in the highest order $(0.13239)$ or in other words this criterion is the criterion that should be prioritized. After that, the extent of lobster's TAC criteria $(\mathrm{C} 1)$ in the source domain is criteria that occupy the second priority. Subsequently followed by criteria of lobster size (C3) (Source Domain) (Figure 1).23

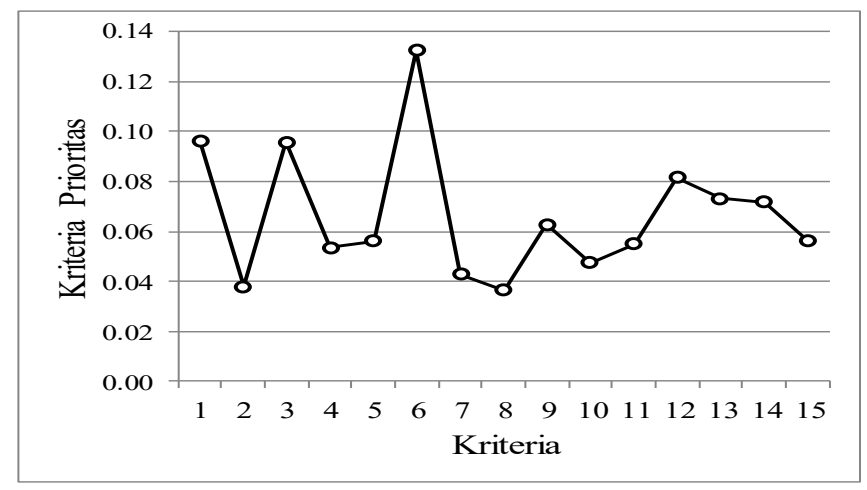

Fig. 1. Weighting criteria from each research domain

According to [24], one of ideal effort to avoid adverse effect for coral reefs ecosystem is directing underwater tourism activities from natural coral reefs to artificial coral reefs. [12] argues that based on calculation result from Travel Suitability Index for diving and snorkeling activities in Pemuteran Beach categorized as appropriate (S2) because it is supported by artificial reefs with bio-rock system.

Tourism industry in Australia prioritizes scuba-diving because it is estimated to increase revenue by 1 billion Australian dollars [6, 11]. Ship that had an accident SS. Yongala, located near the Great Barrier Reef in Queensland, and officially one of the world's best artificial reefs expected to give 1 million Australian dollar s of diving tours every year excluding profits from airlines, accommodation service and restaurant $[6,4,5]$. Brisbane Ship which was sunk in the waters of Sunshine Coast, Australia capable of creating new diving destination that attract about 25,000 divers or at an additional $5 \%$ annually. This 
diving tour generates about 1 million Australian dollars annually and creates about 200 new jobs [7].

\subsection{Priority of management option against EAFM domain criteria}

There are several principles in implementing EAFM among others: (1) Minimized the effect of fisheries to the ecosystem; (2) Precautionary approach should take based on an incomplete information should; (3) Balancing the human and ecosystem welfare and property rights [10]). The weighting result of priority of management option against every EAFM domain shows that option III (Authority needs to ensure both human and ecosystem welfare and property rights) is the alternative with high weight value that is 0.61962 and has a consistency ratio of $9.4 \%$. From the above principles are then translated into policy objectives. The relayions between every criteria and alternatives (options) of management illustrated in flow chart in Figure 2.

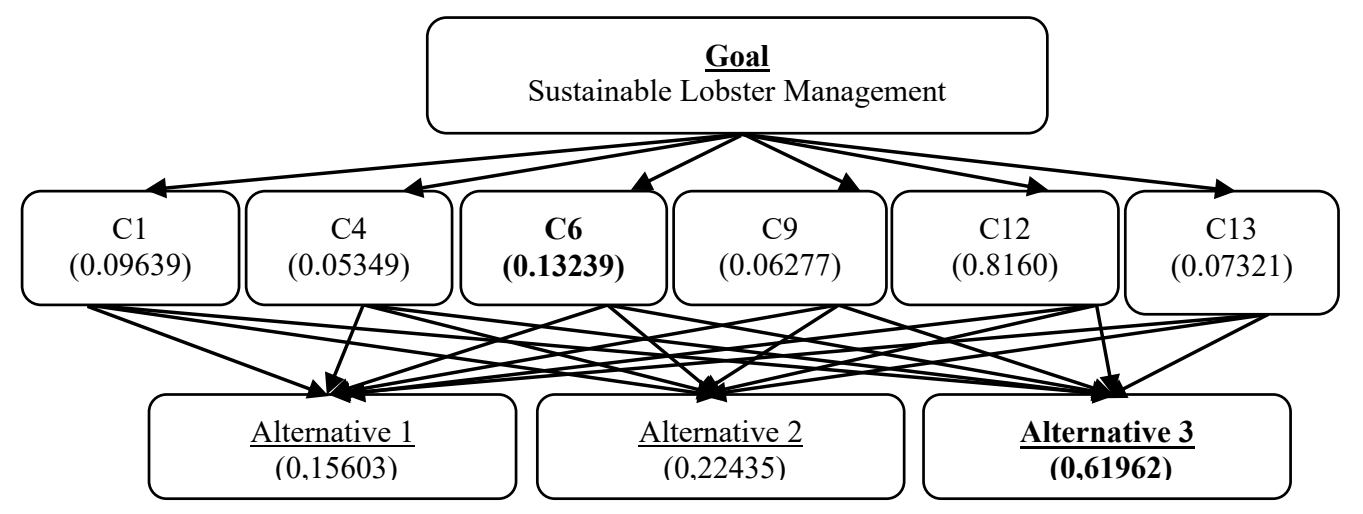

Fig. 2. Flow chart of relation between criteria and alternatives (options) of Lobster in Pangandaran.

Fishery management basically has three components that are inseparable from one another, namely (1) component of fishery resource and their ecosystem; (2) component utilization of fishery resource for socio-economic interest of the community; and (3) component of fishery policy fishery itself [2]. An Ecosystem Approach to Fisheries (EAF) strives to arrange multiple societal objectives into proportional level, by considering uncertainties and information of the ecosystem components and their interactions based on acceptable boundaries [10].

\section{Conclusion}

Based on the results of analysis it is known that the decline in production was influenced by a decrease in the extent of coral cover which is the habitat of lobster so that this needs attention or, in other words, it needs to be prioritized as a consideration in managing lobster resources in Pangandaran. Thus, the right management option is that both central and local governments need to reassure the effectiveness of the regulatory tools for the management of lobsters and conduct continuous and comprehensive lobster stock assessments while considering socioeconomic aspects in the context of sustainable lobster management in the Pangandaran area. 


\section{References}

1. J. S. Cobb \& B. F. Philips, The Biology and Managemenr of Lobsters. New York: Academis Press. (1980).

2. A. T. Charles, Sustainable fishery systems. Wiley. com. (2001).

3. C. Ahmad, Djauhari. Protection of fishery resources to ensure sustainable fisheries development. Journal of Laws Khaira Ummah. Vol. 12 (3): 467-478. (2017).

4. M. Cuthill, Managing the Yongala historic shipwreck. Coastal Management. Vol. 26: 33-46. (1998).

5. J. P. Delgado, The value of shipwrecks. in J Waldron Murphy (ed.), Historic shipwrecks: Issues in management. Partners for Livable Places and the National Trust for Historic Preservation, Washington DC. pp. 1-10. (1988).

6. J. Edney, Impacts of recreational scuba diving on shipwrecks in Australia and the Pacific: A review. Micronesian Journal of the Humanities and Social Sciences. Vol. 5: 201-233. (2006).

7. EPA (Environment Protection Agency), Public benefit test for a proposed conservation park for the ex-HMAS Brisbane. Queensland Government, Brisbane, Queensland. (2005).

8. Erlania, R. I Nyoman, H. Joni, Status of management of lobster seed resources to support aquaculture: Case study of Lombok Island waters.. Jurnal Kebijakan Perikanan Indonesia. Vol. 8 (2): 85-96. (2016)

9. K. Erzini, C. C. Monteiro, J.Ribeiro, M. N. Santos, M. Gaspar, P. Monteiro, T. C. Borges, An experimental study of gill net and trammel net "Ghost fishing" off the Algarve (Southern Portugal). Marine Ecology Progres Series. Vol. 158: 257-265. (1997).

10. S. M. Garcia, The ecosystem approach to fisheries: isus, terminology, principles, institutional foundations, implementation and outlook. Food and Agriculture Organization of the United Nations. Rome. (2003).

11. V. J. Harriott, Marine tourism impacts and their management on the Great Barrier Reef. CRC Reef Research Centre Technical Report No. 46, CRC Reef Research Centre, Townsville, Queensland. (2002).

12. I. N. Ridho, T. A., Irwani. Study of biosphere reef ecosystem compatibility as a diving and snorkeling tourism zone at Pemuteran beach, Bali. Journal of Marine Research. Vol. 3 (4): 667-675. (2014).

13. H. M. M. M. Jayawickarama, A. K. Kulatunga, S. Mathavan, Fuzzy AHP based Plant Sustainability Evaluation Method. Procedia Manufacturing. Vol. 8: 571-578. (2017)

14. M. Kadafi, R. Widaningroem, Soeparno, Biological aspects and potential for sustainable lobster resources (Panulirus spp.) In the coastal waters of Kecamatan Ayah Kebumen District. Journal of Fisheries. Vol. VIII (1): 108-117. (2005)

15. E. S. Kartamihardja, F. Satria, S. T. Hartati, A. Nurfiarini, D. Wijaya, Mujianto, A. Rudi, Ecological Assessment for restocking lobster seeds in Indonesian waters conservation areas. Jatiluhur: Research Institute for Recovery and Conservation of Fish Resources. (2015).

16. K. Namhyun, P. Joungkoo, C. jeong-Ja. Perceptual differences in core competencies between tourism industry practitioners and students using Analytic Hierarchy Process (AHP). Journal of Hospitality, Leisure, Sport \& Tourism Education. Vol. 20:76-86. (2017).

17. Kuncoro, Mudrajad, Autonomy \& regional development, reform, planning, strategy, and opportunities. Jakarta: Erlangga. (2004). 
18. K. R. A. Budi, C. Anne, M. G. Wibawa, Gender analysis in the lives of family fishermen in Pangandaran District, Ciamis Regency. Jurnal Social Economic of Agriculture. Volume 2 (1): 42-53. (2013).

19. B. O. Nababan, S. Y. Dewita, H. Maman, Review of economic aspects of small scale fisheries sustainability in Tegal regency of Central Java. Economics Bulletin of Fisheries. Vol. VIII (2): 50-68. (2008).

20. J. C. Onthoni, Analysis of the use of bombs in fishing in North Kao district of North Halmahera District. Thesis - Bogor Agricultural University. 77p. (2010).

21. B. Permadi, $A H P$. Inter-University Center - Economic Studies University of Indonesia, Jakarta. (1992).

22. T. L. Saaty, A scaling method for priorities in a hierarchichal structure. Journal of Mathematical Psychology. Vol. 15:234-281. (1977).

23. W. Subani, Fishing Tools and Methods in Indonesia. Volume 1. LPPL. Jakarta. (1978)

24. V. P. Treeck, H. Schuhmacher, Mass Diving Tourism - A New Dimension Calls for New Management Approaches. Marine Pollution Bulletin. Vol. 37: 499-504. (1998)

25. A.T. White, C.L Ming, M.W.R.N de Silva, L.Y. Guam Guaria, Artificial reefs for Marine habitat Enhancement in southeas asia, ICLARM Education series 45 p. (1990). 